\title{
Bioindikator Cemaran Timbal pada Rambut Masyarakat Sekitar Kilang Minyak
}

\section{Bioindicator of Lead Contamination in Hair of People around Oil Refinery}

\author{
Sukar*, Suharjo**
}

\begin{abstract}
*Pusat Biomedis dan Teknologi Dasar Kesehatan, **Pusat Teknologi Intervensi Kesehatan Masyarakat Badan Penelitian dan Pengembangan Kesehatan Kementerian Kesehatan RI
\end{abstract}

\begin{abstract}
Abstrak
Timbal atau Plumbum $(\mathrm{Pb})$ bersifat toksik, karsinogenik, bioakumulator dan biomagnifikasi. Bioakumulasi Timbal dari media lingkungan dapat terjadi pada kuku, hati, dan rambut. Tujuan penelitian untuk mengetahui faktor risiko kejadian bioindikator timbal rambut masyarakat di kawasan industri minyak. Penelitian dilakukan pada tahun 2012 di Kota Dumai, Provinsi Riau. Rancangan penelitian khusus pencemaran lingkungan 2012 adalah type1 health study, yang disarankan US Agency for Toxic Substances and Drugs Registry (ATSDR). Analisis statistik bivariat dengan uji kai kuadrat. Populasi penelitian adalah penduduk Kota Dumai yang tinggal di desa Jayamukti, Tanjung Palas, Mekarsari, dan Bukit Timah. Sejumlah 110 ibu rumah tangga diambil dengan teknik purposive sampling. Kriteria inklusi, responden berusia antara 17 - 55 tahun dan telah tinggal minimal selama lima tahun terakhir. Kriteria ekslusi sedang menderita penyakit kronis. Hasil analisis dari enam parameter media lingkungan menunjukkan ada empat parameter berisiko mencemari, tetapi belum bermakna antara parameter lingkungan dan kejadian timbal rambut dengan nilai $p>0,05$. Odds Ratio (OR) terbesar ditunjukkan oleh parameter ikan sebesar 1,5 dan terkecil makanan atau minuman dan tanah 1,13. Proporsi risiko terbesar ditunjukkan oleh parameter ikan sebesar 33,3\% dan terkecil parameter makanan atau minuman 10\%. Telah terjadi penanggulangan risiko untuk parameter air minum dan air permukaan dengan nilai $p<0,05$.
\end{abstract}

Kata kunci: Bioindikator timbal, industri minyak, media lingkungan

\section{Abstract}

Lead or Plumbum $(\mathrm{Pb})$ is toxic, carcinogenic, bioaccumulator and biomagnification. Lead bioaccumulation of environmental media may occur in liver, nails and hair. The study objective was to find out the risk of lead bioindicator occurence in hair of people living in oil industry area. The study was conducted in 2012 in Dumai City, Riau Province. The study design is a type-1 health study, suggested the US Agency for Toxic Substances and Drug Registry (ATSDR). The statistical analysis was bivariate using chi-square test. The population was Dumai City dwellers who lived in the village Jayamukti, Tanjung Palas, Mekarsari and Bukit Timah. A total of 110 housewives were taken by purposive sampling technique. Inclusion, respondents aged between 17 - 55 years old and have lived for five years at minimum. Exclusion criteria was those suffering cronic disease. Analysis results of six parameters of environmental media there were four parameters, had risk of contaminating but not significant between environmental parameters and the lead occurence in hair with $p$ value $>0.05$. The biggest odd ratio $(O R)$ was showed by fish parameter worth 1.5 and the smallest was food or beverage and land worth 1.13. The biggest proportion was showed by fish parameter of $33.3 \%$ and the smallest food or beverage $10 \%$. There has been a reduction of risk for the parameters of drinking water and surface water with $p$ value $<0.05$.

Keywords: Lead bioindicator, oil industry, environmental media

\section{Pendahuluan}

Timbal atau Plumbum $(\mathrm{Pb})$ termasuk logam berat, melimpah di alam dan mudah terdistribusi ke bagian lain lingkungan. Timbal bersifat resisten, korosif, padat dan memiliki titik lebur rendah. Timbal digunakan masyarakat untuk melapisi pipa besi, pengelasan, dan batu baterai. Bila terpapar timbal, terutama udara dan air, akan membentuk lapisan timbal karbonat, oksida, dan sulfat, maka akan terserap oleh media lingkungan. ${ }^{1}$

Timbal yang ditambahkan pada bahan bakar sebagai antiknocking mesin dikenal sebagai bensin beroktan merupakan sumber racun timbal dari kendaraan. Timbal yang berasal dari bensin beroktan tersebut mengontami-

Korespondensi: Sukar, Pusat Biomedis dan Teknologi Dasar Kesehatan, Balitbangkesmas Kemenkes RI, Jl. Percetakan Negara No 29 Jakarta Pusat, No. Telp: 0736-341212,e-mail: sukarsulisomo@yahoo.com 
nasi media lingkungan dan akan meningkatkan kandungan timbal dalam darah, terutama pada anak-anak di daerah perkotaan. Timbal masuk ke dalam tubuh manusia melalui pelbagai cara antara lain ketika bernapas, makan, menelan, atau minum. Masyarakat yang tinggal di pantai memiliki kebiasaan mengonsumsi ikan atau kerang sehingga kemungkinan juga terjadinya akumulasi dan biomagnifikasi. Akumulasi timbal dalam tubuh, dapat dideteksi dari darah, tulang dan rambut. Pada rambut, timbal terikat kuat pada gugus sulfihidril sehingga kandungan timbal pada rambut dapat dijadikan indikator pencemaran timbal dari lingkungan.2,3

Penelitian pencemaran timbal di lingkungan khususnya udara telah dilakukan di Semarang Utara, menemukan kadar timbal udara pada musim kemarau rata-rata $8,41 \mu \mathrm{g} / \mathrm{m}^{3} .{ }^{4}$ Kadar timbal juga terdeteksi dalam sistem organ ikan mas, ikan bandeng, dan ikan pada Waduk Saguling, Jawa Barat. ${ }^{5-7}$ Kadar timbal tersebut telah melampaui nilai ambang baku mutu lingkungan yang tercantum dalam Peraturan Pemerintah Nomor 41/1999 yaitu, maksimal $2 \mu \mathrm{g} / \mathrm{m}^{3}$.

Timbal tidak dibutuhkan dalam proses fisiologis manusia. Kehadiran yang berlebihan akan menurunkan mutu pemanfaatan air dalam tubuh, selain itu juga daya racunnya sangat kuat. Oleh karena itu, sangat diperlukan pengukuran dan kontrol terhadap tingkat konsentrasinya pada media lingkungan. ${ }^{1}$

Bila timbal terakumulasi dalam tubuh manusia, dapat merusak fungsi mental serta kerusakan serius pada sistem saraf, mengubah perilaku, dan menyebabkan anemia. Apabila tingkat keracunan berat dapat menyebabkan muntah-muntah dan memungkinkan gangguan kesehatan. Timbal dapat merusak dengan pelbagai cara seperti pengurangan sel-sel darah merah, penurunan sintesis hemoglobin, dan penghambatan sintesis heme yang menimbulkan anemia. Selain itu, timbal dalam tulang dapat mengganti kalsium yang menyebabkan kelumpuhan. Half live dalam tulang 600 - 3.000 hari. ${ }^{3,8}$

Metode praktis dan relatif mudah untuk mengetahui tingkat pencemaran timbal di lingkungan yang telah berdampak ke tubuh penduduk adalah dengan menganalisis timbal rambut sebagai bioindikator. Tujuan penelitian adalah untuk mengetahui faktor bioindikator timbal dari media lingkungan terhadap masyarakat, terutama tinggal di kawasan industri minyak.

\section{Metode}

Rancangan Riset Khusus Pencemaran Lingkungan (Rikhus Cemarling) 2012 adalah health study type-1, yang disarankan US Agency for Toxic Substances and Drugs Registry (ATSDR). Penelitian mengukur tingkat timbal pada media lingkungan sebagai faktor risiko dan rambut penduduk sebagai target. Penelitian dilakukan bulan Januari hingga Desember 2012 di Kota Dumai,
Provinsi Riau.

Populasi penelitian adalah penduduk Kota Dumai yang tinggal di Kecamatan Dumai Timur (Desa Jayamukti dan Tanjung Palas) dan Dumai Selatan (Desa Mekarsari dan Bukit Timah). Variabel bebas merupakan media lingkungan yang terdiri dari air minum, air permukaan, makanan/minuman, tanah, udara outdoors, dan ikan. Sedangkan variabel terikat/tergantung adalah biomarker kadar timbal rambut yang diambil dengan random sampling penduduk Wanita Usia Subur (WUS) sejumlah 110 dengan inklusi berusia17 - 50 tahun tinggal di lokasi penelitian dan eksklusi sedang menderita penyakit kronis.

Penentuan bahwa telah terjadi dampak kesehatan dari cemaran timbal dari media lingkungan apabila nilai odd ratio $(\mathrm{OR}) \geq 1$ dan bermakna apabila 95\% CI tidak melewati nilai absolut. Kategori berisiko apabila kadar timbal pada media lingkungan lebih dari sama dengan limit deteksi alat analisis dan tidak berisiko apabila kadar timbal pada media lingkungan kurang dari limit deteksi alat. Alat yang digunakan untuk analisis adalah Atomic Absoprtion Spectrophotometri (AAS), tipe 932 AA. Sedangkan batasan timbal rambut apabila kadar timbal rambut lebih dari sama dengan limit deteksi alat analisis dan nontimbal rambut bila kadar timbal pada media lingkungan kurang dari limit deteksi. Sebelum pelaksanaan penelitian, dilakukan pelatihan terhadap anggota tim peneliti. Selanjutnya, tim peneliti melakukan pelatihan kepada pengumpul data. Tim pengumpul data terdiri dari staf kesehatan dari Dinas Kesehatan dan Puskesmas Kota Dumai yang koordinasi oleh peneliti dari Badan Penelitian dan Pengembangan Kesehatan. Selain itu, juga dilakukan uji coba analisis kadar timbal untuk validasi terhadap alat digunakan. Analisis data statistik meliputi univariat, bivariat dengan uji kai kuadrat.

\section{Hasil}

Hasil analisis univariat kadar timbal pada media lingkungan parameter air minum, dari 354 sampel air minum sebanyak 216 sampel (61\%) kadar timbal berisiko dan air permukaan dari enam titik pengambilan sebanyak empat sampel $(66,7 \%)$ kadar timbal berisiko dan tidak berisiko dua sampel (33,3\%). Titik pengambilan yang masing-masing titik merupakan komposit dari tiga frekuensi pengambilan (pinggir 1, tengah, dan pinggir 2) serta tiga frekuensi waktu (pagi, siang, dan sore). Untuk tanah, dari 20 sampel, kadar timbal berisiko sebanyak 17 sampel (85\%). Asupan timbal dari makanan atau minuman dari 10 sampel, enam (75\%) di antaranya berisiko. Sedang asupan dari tanah, 17 dari 20 sampel kadar timbal berisiko (85\%). Asupan dari ikan 10 sampel, enam sampel (75\%) diantaranya berisiko dan asupan dari udara di luar rumah (outdoors air), 12 dari 20 sampel diantaranya berisiko $(60 \%)$. Outdoors air yang 
Tabel 1. Distribusi Frekuensi Media Lingkungan terhadap Kadar Timbal

\begin{tabular}{|c|c|c|c|c|c|c|c|c|}
\hline \multirow{2}{*}{ Variabel } & \multirow{2}{*}{ Kategori } & \multicolumn{2}{|c|}{ Timbal Rambut } & \multicolumn{2}{|c|}{ Non-Timbal Rambut } & \multirow{2}{*}{ OR } & \multirow{2}{*}{ Nilai p } & \multirow{2}{*}{$95 \% \mathrm{CI}$} \\
\hline & & $\mathbf{n}$ & $\%$ & $\mathbf{n}$ & $\%$ & & & \\
\hline \multicolumn{9}{|l|}{ Asupan timbal pada: } \\
\hline \multirow[t]{2}{*}{ Air minum } & Berisiko & 81 & 45,8 & 135 & 76,3 & 0,6 & 0,00 & $0,5-0,7$ \\
\hline & Tidak berisiko & 96 & 54,2 & 42 & 23,7 & & & \\
\hline \multirow{2}{*}{ Air permukaan } & Berisiko & 2 & 66,7 & 3 & 100 & 0,7 & 0,4 & $0,3-1,6$ \\
\hline & Tidak berisiko & 1 & 33,3 & 0 & 0 & & & \\
\hline \multirow[t]{2}{*}{ Makanan/minuman } & Berisiko & 9 & 90 & 8 & 80 & 1,13 & 0,5 & $0,78-1,6$ \\
\hline & Tidak berisiko & 1 & 10 & 2 & 20 & & & \\
\hline \multirow[t]{2}{*}{ Tanah } & Berisiko & 9 & 90 & 8 & 80 & 1,13 & 0,5 & $0,78-1,6$ \\
\hline & Tidak berisiko & 1 & 10 & 2 & 20 & & & \\
\hline \multirow[t]{2}{*}{ Ikan } & Berisiko & 3 & 66,7 & 2 & 50 & 1,5 & 0,46 & $0,5-4,7$ \\
\hline & Tidak berisiko & 1 & 33,3 & 2 & 50 & & & \\
\hline \multirow[t]{2}{*}{ Outdoors air } & Berisiko & 8 & 80 & 6 & 60 & 1,3 & 0,34 & $0,74-2,4$ \\
\hline & Tidak berisiko & 2 & 20 & 4 & 40 & & & \\
\hline \multicolumn{9}{|l|}{ Luaran timbal: } \\
\hline \multirow[t]{2}{*}{ Rambut } & Berisiko & 49 & 98 & 59 & 98,3 & 1,0 & 0,9 & $0,95-1,1$ \\
\hline & Tidak berisiko & 1 & 2 & 1 & 1,7 & & & \\
\hline
\end{tabular}

diukur adalah debu particulate matters (PM) berdiameter $\leq 10 \mu \mathrm{m}$. Sedangkan luaran timbal rambut berisiko sebanyak 108 sampel $(98,2 \%)$ dan tidak berisiko dua sampel $(1,8 \%)$. Analisis univariat enam jenis media lingkungan menunjukkan bahwa kadar timbal terdeteksi terbanyak dari makanan/minuman dan tanah masingmasing $85 \%$, disusul air permukaan, ikan, air minum terakhir udara luar ruang.

Analisis bivariat kategori risiko pada media lingkungan berdasarkan kadar timbal rambut disajikan pada Tabel 1. Perhitungan bivariat enam media lingkungan menujukkan bahwa nilai OR terbesar adalah timbal dari ikan yaitu $1,5(95 \% \mathrm{CI}=0,5-4,7)$, disusul dengan media lingkungan makanan/minuman, tanah dan udara luar ruang. Sedangkan, yang belum mempunyai risiko adalah air minum dan air permukaan dengan nilai $\mathrm{OR}<$ 1. Sementara itu, untuk air minum sangat bermakna tidak berisiko (penanggulangan), yaitu ditunjukkan dengan nilai $\mathrm{p}<0,05$. Indikator keterpaparan kadar timbal pada kesehatan ditunjukkan luaran dari timbal rambut dengan nilai OR sebesar 1,0 $(95 \% \mathrm{CI}=0,95-1,1)$ dengan nilai signifikansinya 0,9 . Media lingkungan yang dianalisis tidak satupun yang signifikan berisiko terhadap kesehatan sehingga tidak dilakukan analisis multivariat.

\section{Pembahasan}

Analisis timbal menggunakan rambut karena selain sebagai bioindikator cemaran, juga dapat mengukur kandungan nutrisi, tingkat keracunan, keseimbangan antara tingkat nutrisi dan tipe metabolisme timbal dalam tubuh. Analisis timbal pada rambut memiliki keuntungan lebih karena memiliki jangka waktu memori cukup panjang bahkan hasil yang permanen. Rambut kepala tumbuh dengan kecepatan rata-rata setengah inci ( 1 inci $=2,54$ centimeter) per bulan. Oleh karena itu, tiga inci dari rambut manusia dapat menceritakan sejarah yang terjadi pada tubuh manusia selama enam bulan. ${ }^{9}$

Kandungan timbal dalam air minum, termasuk air hujan yang dimanfaatkan untuk memasak dan minum relatif sama antara kategori berisiko dan tidak berisiko, yaitu $0,01 \geq \mathrm{ppm}$ dan $<0,01 \mathrm{ppm}$. Nilai tersebut masih di bawah batas ambang batas yang tertuang dalam Surat Keputusan No. 02/MEN KLH/III/1988 untuk air golongan A dan B (air minum) 0,05 ppm, C (perikanan dan peternakan) 0,03 ppm serta air golongan $\mathrm{D}$ (pertanian) 1,00 ppm. ${ }^{10}$ Dibandingkan dengan penelitian lain yang menganalisis air minum berasal dari air sumur bor di Kelurahan Keteguhan, Lampung mendapatkan kadar logam timbal dalam air rata-rata $0,2753 \mathrm{mg} / \mathrm{L}$, dengan kadar tertinggi timbal $0,4691 \mathrm{mg} / \mathrm{L}$ dan kadar terendah $0,1975 \mathrm{mg} / \mathrm{L}$, penelitian ini jauh lebih baik. ${ }^{11}$ Begitu juga bila dibandingkan dengan penelitian air minum isi ulang di Purwokerto, Jawa Tengah yang telah mengalami proses filtrasi dan sterilisasi kadar timbal terkecil adalah sebesar 1,14 ppm dan terbesar 17,5 ppm, dengan hasil penelitian ini juga masih jauh lebih baik. ${ }^{12}$ Analisis risiko penelitian ini didapat $87,8 \%$ masyarakat berisiko mengalami gangguan kesehatan akibat logam timbal.

Kandungan timbal air permukaan kategori berisiko $66,7 \%$ dengan kadar $\geq 0,03$ ppm. Kandungan timbal air hujan dan air aliran permukaan relatif sama antara berisiko dan tidak berisiko. Berdasarkan Peraturan Pemerintah Republik Indonesia No. 82/2001 tentang Pengelolaan Kualitas Air dan Pengendalian Pencemaran Air, baku mutu untuk kadar timbal adalah 0,03 ppm. ${ }^{10}$ Dibandingkan dengan Peraturan Pemerintah tersebut, berarti sebagian besar dari kualitas air permukaan pada penelitian ini telah melebihi baku mutu untuk timbal. 
Namun, bila dibandingkan dengan hasil penelitian di Perairan Situbondo yang mendapatkan kadar timbal antara 0,0018-0,0032 ppm (kadar tertinggi 0,0032 ppm) yang terukur di pantai dekat sungai, menunjukkan bahwa penelitian di Dumai telah melewati kadar tersebut. ${ }^{13,14}$ Kandungan timbal dalam air aliran permukaan sangat beragam dengan rata-rata $0,07 \mathrm{ppm}$, nilai tersebut berada di atas batas ambang untuk air golongan A, B, C, tetapi lebih rendah untuk air golongan D. Kontaminasi logam berat timbal pada lingkungan perairan merupakan masalah besar dunia saat ini. Persoalan spesifik logam berat timbal di lingkungan terutama karena akumulasinya sampai pada rantai makanan. Keberadaan di alam, timbal sangat mencemari tanah, udara dan air. Proses industri dan urbanisasi memegang peranan penting terhadap peningkatan kontaminasi tersebut. ${ }^{15-18}$

Presentase kandungan timbal pada makanan/minuman kategori berisiko adalah $85 \%$. Hal ini menunjukkan bahwa kadar timbal sebesar $85 \%$ pada makanan/minuman telah melebihi baku mutu yang dikeluarkan oleh Standar Nasional Indonesia (SNI) 7387 tahun 2009 tentang batas maksimum cemaran timbal dalam pangan, yaitu sebesar $0,25 \mathrm{mg} / \mathrm{kg}$ (ppm). Walaupun peraturan Badan Pengawasan Obat dan Makanan Republik Indonesia (BPOM RI) No. 03725/B/SK/VII/1989 mengatur kadar timbal maksimal dua ppm, penelitian ini mengunakan batas aman dari SNI 7378. Penelitian yang dilakukan terhadap kandungan timbal dalam makanan gorengan yang dijual di pinggir jalan di kawasan Malioboro, Yogyakarta menunjukkan bahwa tidak semua sampel positif mengandung timbal atau di bawah limit deteksi. Dari sampel yang positif mengandung kadar timbal, tercatat sebanyak 61,9\% dengan kisaran konsentrasi $0,003-0,531 \mathrm{ppm}$. Uji coba pengambilan sampel dengan beda waktu menunjukkan bahwa uji t terhadap sampel yang diambil pada pukul 12.00 WIB dibandingkan dengan sampel yang diambil pada pukul 16.00 WIB menunjukkan tidak ada perbedaan bermakna antara keduanya pada taraf signifikansi 95\%. ${ }^{17,19}$ Jika dibandingkan dengan penelitian di kawasan Malioboro dan Dumai, variasi kadar timbal hampir sama. Namun, jika dibandingkan dengan hasil pemantauan Badan Pengendalian Dampak Lingkungan Daerah (Bapedalda) DKI Jakarta, kadar timbal makanan/minuman yang dijual dekat jalan padat lalu lintas mengandung timbal di atas ambang batas yang ditentukan oleh BPPOM RI dan World Health Organization (WHO). Terdeteksi kadar timbal antara 15,5-29,9 ppm, jauh lebih tinggi. Terlebih pada makanan jajanan yang dijual di sekitar terminal bus tidak terhindarkan lagi dari kontaminasi. ${ }^{13,19}$ Perlu upaya pemahaman terhadap anak-anak maupun orangtua mengenai keberadaan timbal di lingkungan dan efek terhadap kesehatan. ${ }^{20}$

Kandungan timbal tanah kategori berisiko $80 \%$ dan tidak berisiko $20 \%$, menunjukkan bahwa $80 \%$ timbal pada tanah maksimum $30 \mathrm{mg} / \mathrm{kg}$ (ppm). ${ }^{16}$ Dibandingkan dengan hasil analisis timbal dalam tanah yang terkontaminasi sludge dengan rata-rata $63,1 \mathrm{mg} / \mathrm{kg}$, menunjukkan hasil di Dumai masih lebih baik. Sedangkan, penelitian dampak emisi kendaraan bermotor terhadap tanah di lahan pertanian dan nonpertanian dengan jarak dari tepi jalan yaitu lima meter, 15 meter, 30 meter, dan kedalaman tanah empat sentimeter dan delapan centimeter menunjukan bahwa rata-rata kandungan timbal pada tanah di lahan pertanian $31,183 \mathrm{mg} / \mathrm{kg}$ dan nonpertanian adalah $38,981 \mathrm{mg} / \mathrm{kg}$. Hal ini berarti kandungan logam timbal dalam tanah rata-rata di Dumai hampir sama dengan tanah pertanian yang terkontaminasi udara transportasi. Kandungan timbal tanah antara 10 $30 \mathrm{mg} / \mathrm{kg}$ berdampak pada keracunan ternak. ${ }^{21}$ Menurut Komite Pembebasan Bensin Bertimbal, yaitu sebuah lembaga swadaya masyarakat bekerja sama dengan Blacksmith Institute dari Amerika Serikat, mengungkap bahwa kadar timbal dalam tanah di Desa Cinangka, Kecamatan Ciampea, tidak jauh dari Kota Bogor, Jawa Barat, mencapai 270.000 ppm. Hal tersebut menyebabkan belasan anak dengan gangguan mental. ${ }^{15}$

Kandungan timbal kategori berisiko pada ikan (sejenis) menunjukkan $75 \%$, dan sisanya $25 \%$ tidak berisiko. Hal ini berarti kadar timbal dalam ikan $75 \%$ telah melebihi 2,0 ppm. Surat Keputusan Direktorat Jenderal Pengawasan Obat dan Makanan No. 03725/B/SK/ VII/89 adalah batas maksimum untuk timbal pada ikan sebesar $2 \mathrm{mg} / \mathrm{kg}$. Dibandingkan dengan hasil penelitian di perairan sungai, Banda Aceh dengan lokasi masingmasing sungai Lambaro, Lamnyong dan Pantee Pirak rata-rata hasil analisis kandungan logam timbal adalah 0,1327 ppm; 0,1509 ppm; dan 0,1390 ppm. Sementara hasil analisis kerang masing-masing sungai pada lokasi yang sama adalah 0,0165 ppm; 0,0279 ppm; dan 0,0194 ppm. ${ }^{22-25}$ Hasil ini menunjukkan bahwa kadar timbal pada ikan dan kerang masih lebih baik dibandingkan di Dumai. Selain itu, dalam hasil penelitian pada tangkapan ikan gabus di Makassar berkisar antara 2,04 - 2,95 ppm. ${ }^{26}$ Hasil penelitian ini walaupun sudah melebihi ambang batas BPOM juga hampir sama dibandingkan di Dumai. Dibandingkan dengan hasil penelitian di perairan Situbondo yang mendapatkan kadar timbal pada ikan antara 0,2298 - 1,3625 ppm, hasil penelitian di Dumai sudah mengkhawatirkan. ${ }^{14}$ Sedangkan uji coba penyerapan timbal oleh ikan yang dilakukan selang waktu satu jam menunjukkan serapan sebanyak 0,21 ppm. 23,24

Kandungan timbal kategori berisiko pada debu udara dengan diameter $10 \mu \mathrm{m}$ yang dikenal dengan PM10 menunjukkan kisaran $60 \%$ dan $40 \%$ tidak berisiko. Baku mutu timbal udara dalam debu PM10 menurut Peraturan Menteri Kesehatan Republik Indonesia (Permenkes), No. 41/1999 adalah 2,0 $\mu \mathrm{g} / \mathrm{m}$. Jadi, dibandingkan dengan 
Permenkes tersebut menunjukkan bahwa kadar timbal udara di Dumai telah melebihi baku mutu sebanyak $60 \%$. Dibandingkan dengan data yang dikeluarkan Badan Pengendalian Dampak Lingkungan Daerah (Bapepalda) DKI Jakarta tahun 2008, kadar timbal debu udara PM10 telah mencapai 0,5 $\mu \mathrm{g} / \mathrm{m}$. Untuk kawasan tertentu, seperti terminal bus dan daerah padat lalu lintas seperti daerah Pulogadung, kadar timbal bisa mencapai $2-8 \mu \mathrm{g} / \mathrm{m}$. ${ }^{3}$ Hal ini berarti kadar timbal debu udara Dumai sudah mendekati kawasan-kawasan seperti di Jakarta. ${ }^{27-29}$ Kandungan timbal yang tinggi dalam udara menggambarkan bahwa di daerah tersebut sering terjadi polusi yang tinggi. Seperti diketahui bahwa timbal dapat dihasilkan dari sisa pembakaran dari kendaraan bermotor dan pabrik. Tingginya kandungan timbal di daerah tersebut dapat disebabkan karena merupakan daerah industri. Pulogadung juga merupakan terminal bus antarkota terpadat di Jakarta.

Di pelbagai negara, timbal sangat diperhatikan dalam pembahasan polutan di udara, karena merupakan unsur beracun yang sangat membahayakan kesehatan baik lingkungan maupun manusia. Peningkatan polusi tersebut menyebabkan tekanan darah tinggi bagi orang dewasa dan sangat memengaruhi sistem otak dan syaraf pada anak-anak. ${ }^{24}$ Sumber utama pencemaran timbal dalam udara di kota-kota di Asia ialah emisi kendaraan, karena timbal tetra etil dan alkil merupakan senyawa tambahan yang murah guna menaikkan jumlah oktan bahan bakar. 4,30

\section{Kesimpulan}

Berdasarkan hasil analisis dan pembahasan, maka dapat diambil kesimpulan, media lingkungan berhubungan dengan bioindikator timbal rambut. Hal ini dibuktikan oleh empat parameter media lingkungan (makanan atau minuman, tanah, ikan, dan debu udara) dengan nilai OR $>1$, berarti ada risiko. Selain itu, juga terbukti dengan nilai $\mathrm{OR}=1$, untuk biomarker rambut yang menyatakan telah memiliki risiko.

\section{Saran}

Berdasarkan kesimpulan tersebut, dan sesuai dengan tujuan untuk mengetahui adanya pencemaran timbal, disarankan kepada Kementerian Kesehatan, Kementerian Industri, dan Kementerian Lingkungan Hidup agar melakukan langkah strategis untuk menurunkan prevalensi tersebut, antara lain dengan cara pengendalian pencemaran lingkungan. Penyuluhan tentang bahaya dari pencemaran timbal dari lingkungan diperlukan karena faktor ini merupakan faktor dominan terhadap kejadian penyakit yang disebabkan oleh timbal. Penelitian lebih lanjut perlu dilanjutkan dengan menggunakan variabelvariabel lingkungan hasil pengukuran dan penelitian yang menggunakan desain dapat menentukan hubungan kausal antara lingkungan dan kejadian bioindikator timbal sehingga dapat dihasilkan rekomendasi intervensi lebih baik.

\section{Ucapan Terima Kasih}

Ucapan terima kasih kepada Kepala Badan Penelitian dan Pengembangan Kesehatan, Kepala Pusat Teknologi Intervensi Kesehatan dan Kepala Dinas Kesehatan Dumai beserta staf. Kepada rekan peneliti khususnya Asep Hermawan, dan Miko Hananto yang membantu terlaksananya kegiatan.

\section{Daftar Pustaka}

1. Department of Health Otsego County. Lead poisoning prevention: What is Lead? [online] Newyork: Department of Health Otsego County; 2007 [cited 2014 Aug 6]. Available from: otsegocounty.com/depts/doh/ LeadPrevention.htm.

2. The Children's Hospital at Westmead \& Hunter Children's Health Network. Fact sheet: Lead, Kids Health, The Children's Hospital at Westmead \& Kaleidoscope, Hunter Children's Health Network [online]. 2005 [cited 2008 Nov $29^{\text {th }}$ ]. available from: www.chw.edu.au/parents/kidshealth/safety_factsheets/pdf/lead.pdf.

3. Lanphear BP, Hornurg R, Khoury J, Yolton K, baghurst P, Bellinger DC, et al. Low-Level Environmental Lead Exposure and Children's Intellectual Function: an International Pooled Analysis. Environmental Health Perspectives. 2005; 113: 894-9.

4. Martuti NKT. Tingkat kualitas udara di Jalan Protokol Kota Semarang [laporan penelitian]. Semarang: Lembaga Penelitian dan Pengabdian UNNES; 2011.

5. Siregar, YI; Zamri, A, dan Putra, H (2012), Penyerapan timbal (Pb) pada sistem organ ikan mas (Cyprinus carpio L). Jurnal Lingkungan. 2012: 6(1).

6. Purnomo T, Muchyiddin. Analisis kandungan timbal $(\mathrm{Pb})$ pada ikan bandeng (chanos chanos forsk.) di tambak Kecamatan Gresik. Neptunus. 2007; 14(1): 68-77.

7. Jovita TM, Novalia R. Kandungan logam berat pada ikan, air dan sedimen di Waduk Saguling Jawa Barat. Jurnal Pascapanen dan Bioteknologi Kelautan dan Perikanan. 2007; 2(2).

8. Lubis H, Aman C. Pemeriksaan kandungan logam merkuri, timbal, dan kadmium dalam daging rajungan segar yang berasal dari TPI Gabion Belawan secara spektrofotometri serapan atom. Majalah Kedokteran Nusantara. 2008; 41(1).

9. Sanna EL, Vargiu I, Rossetti E, Vallascas, Floris G. CoORelation between blood and hair lead levels in boys and girls of Sardinia (Italy). Journal of Anthropological Sciences. 2007; 85: 173-81.

10. Notodarmojo S. Pencemaran tanah dan air tanah. Bandung: Penerbit ITB; 2005.

11. Budianto A. Analisis risiko kadar timbal $(\mathrm{Pb})$ dalam air sumur terhadap kesehatan masyarakat di Kelurahan Keteguhan Kecamatan Teluk Betung Barat, Kota Bandar Lampung [Kumpulan Judul KTI]. Bandar Lampung; Poltekkes Tanjung Karang; 2012.

12. Rahayu WS, Utami PI, Sari YR. Identifikasi cemaran logam timbal dalam air minum isi ulang yang beredar di Porwokerto dengan metode spektrofotometri serapan atom [laporan penelitian]. Purwokerto: 
Fakultas Farmasi Universitas Muhammadiyah; 2012.

13. Hardiani H, Kardiansyah T, Sugesty. Bioremediasi logam timbal dalam tanah terkontaminasi limbah (sludge) industri kertas proses deinking [laporan penelitian]. Bandung: Balai Besar Pulp dan Kertas; 2011.

14. Handajani H. Kandungan logam berat pada contoh air dan ikan budidaya di Perairan Situbondo. GAMMA. 2011; 6 (2): 95 - 100.

15. Hydro Water Solution (HWS. Bahaya kontaminasi logam berat timbal pada makanan [online]. 2014 [diakses tanggal 15 Febr 2014]. Diunduh dalam: www.fishyforum.com.

16. Notohadiprawiro. Logam berat dalam pertanian, ilmu tanah. Yogyakarta: Universitas Gajah Mada; 2006.

17. Widowati W, Sastiono A, Jusuf R. Efek toksik logam: pencegahan dan penanggulangan pencemaran. Yogyakarta: Penerbit Andi; 2008.

18. Klevay LM, Christopherson DM, Shuler TR. Hair as biopsy material: trace element data on one man over two decades. European Journal of Clinical Nutririon. 2004; 58(10): 1359-64.

19. Annisa, F, Antuni, W, Dyah P. Studi kandungan timbal dalam gorengan yang dijual di pinggir jalan Malioboro, Buku Prosiding Seminar Nasional Penelitian, Pendidikan dan Penerapan MIPA. Yogyakarta UNY Fakultas Farmasi, 2 Juni 2012. Yogyakarta: Universitas Negeri Yogyakarta; 2012.

20. Jones AL. Emerging aspects of assessing lead poisoning in Childhood, Emerging Health Threats Journal. 2009; 2 (2): 2-9.

21. Nurjaya, dkk. 2006. Pengaruh amelioran terhadap kadar Pb tanah, serapannya serta hasil tanaman bawang merah pada inceptisol. Jurnal IlmuIlmu Pertanian Indonesia. 2010; 8 (2): 110-9.
22. Febrita E, Suwondo, Umairah D. Kandungan logam $\mathrm{Pb}$ dan $\mathrm{Cu}$ pada Sipetang (Pharus sp) sebagai bioindikator kualitas perairan di Bengkalis. Jurnal Biogenesis. 2006; 2(2): 41-6.

23. Supriatno dan Lelifajri. Analisis logam berat $\mathrm{Pb}$ dan $\mathrm{Cd}$ dalam sampel ikan dan kerang secara spektrofotometri serapan atom. Jurnal Rekayasa Kimia dan Lingkungan. 2009; 7 (1): 5-8.

24. Rahman A. Kandungan logam berat timbal $(\mathrm{Pb})$ dan $\operatorname{kadmium}(\mathrm{Cd})$ pada beberapa jenis krustasea di Pantai Batakan dan Takisung Kabupaten tanah laut Kalimantan Selatan. Bioscientiae. 2006; 3(2): 93-101.

25. Ashar T, Santi DN, Naria E. Kromium, timbal dan merkuri dalam air sumur masyarakat di sekitar tempat pembuangan akhir sampah. Kesmas: Jurnal Kesehatan Masyarakat Nasional. 2013; 7 (9): 408-14.

26. Hamka L, Sitti S, Hartono. Analisis kandungan timbal pada ikan gabus Hasil Tangkapan di Kota Makasar. Prosiding Seminar Nasional BiologiIPA 2013. Makassar: Universitas Negeri Makassar; 2013.

27. Gusnita D. Pencemaran logam berat timbal $(\mathrm{Pb})$ di udara dan upaya pengapusan bensin bertimbal. Berita Dirgantara. 2012; 13 (3): 95-101.

28. Badan Pengendalian Dampak Lingkungan Daerah (Bapeldalda). Laporan Monitoring Lingkungan Jakarta: Badan Pengendalian Dampak Lingkungan Daerah (Bapeldalda); 2008.

29. Subbid Pemantauan Pencemaran BPLH Bandung. Uji Pb dalam darah anak-anak sekolah dasar di Bandung tahun 2008. Bandung: BPLH.

30. Ardyanto $\mathrm{D}$. Deteksi pencemaran timah hitam $(\mathrm{Pb})$ dalam darah masyarakat yang terpajan timbal (Plumbum). Jurnal Kesehatan Lingkungan. 2005; 2 (1): 67-8. 